\title{
MICROMETEOROLOGICAL ENVIRONMENTS AND BIODIVERSITY IN A CLOSED FOREST AND AT A TREE-FALL GAP IN CENTRAL AMAZONIA
}

\section{AMBIENTES MICROMETEOROLÓGICOS E A BIODIVERSIDADE FLORÍSTICA EM FLORESTA FECHADA E EM CLAREIRA NATURAL NA AMAZÔNIA CENTRAL}

\author{
Akio Tsuchiya ${ }^{1}$ Akira Tanaka $^{2}$
}

\begin{abstract}
Micrometeorological parameters were measured in a closed forest (CF) and at a tree-fall gap (LG) near Novo Aripuanã, AM, along the Madeira River in dry season (August to September 2003) and rainy season (March 2004), and were compared to the number of species per family and the number of seedlings obtained from forest inventory. The daily averages of net radiation $\left(\mathrm{W} / \mathrm{m}^{2}\right)$ between CF and LG were 9.5:168.0 during dry season and 3.6:125.9 during rainy season, and these averages were influenced by the difference in shortwave radiation between the sites $(\mathrm{CF}<\mathrm{LG})$. Likewise, the diurnal range of soil heat flux, soil temperature, air temperature, and saturation deficit were all $\mathrm{CF}<\mathrm{LG}$. These site differences were explained from the sky-view factor (CF: $14.8 \pm 3.9 \%$, LG: $43.6 \pm 6.0 \%$ ). Frequently-occurring tree-falls and recoveries resulted in increases in the numbers of colonizer species, such as Burseraseae, Cecropiaceae, Meliaceae, Myristicaceae, Simaroubaceae, Violaceae, and Sterculiaceae. From the comparison of the number of seedlings at mini-plots, some genera, which have established themselves in response to improvements in environments at gaps, were found, such as Pourouma, Parkia, Tachigalia, and Orbignya, meanwhile genera peculiar to closed forests (Protium, Chrysophyllum, Micropholis) were also found.
\end{abstract}

Keywords: micrometeorological environments; closed forest; tree-fall gap; biodiversity.

\section{RESUMO}

Diversos parâmetros micrometeorológicos foram medidos em floresta fechada (CF) e em clareira natural (LG) na região do Rio Madeira, município de Novo Aripuanã, Estado do Amazonas, na estacão seca (agosto a setembro, 2003) e na estacão chuvosa (março, 2004). Os resultados foram relacionados com o número de espécies por família e a regeneração natural de um inventário florístico. A amplitude da radiação líquida diurna (Rn: W/m ${ }^{2}$ ) entre CF e LG foi de 9,5 e 168,0, respectivamente, durante a estação seca, e 3.6 e 125.9 durante a estacão chuvosa. A média dos valores foi influenciada pela diferença da radiação de onda curta entre sítios $(\mathrm{CF}<\mathrm{LG})$. Da mesma maneira, o fluxo de calor no solo no período diurno, a temperatura do solo, temperatura do ar e o déficit de saturação apresentaram a relação de $\mathrm{CF}<\mathrm{LG}$. As diferenças entre as

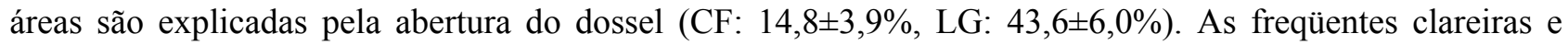
reconstruções da floresta resultam no aumento das espécies colonizadores, como Burseraseae, Cecropiaceae, Meliaceae, Myristicaceae, Simaroubaceae, Violaceae, e Sterculiaceae. Na comparação quantitativa de regeneração natural em sub-parcelas, foi observada a ocorrência de gêneros aptos a clareiras tais como Pourouma, Parkia, Tachigalia e Orbignya, e de gêneros comuns em ambiente de floresta fechada (Protium, Chrysophyllum, Micropholis).

Palavras-chave: ambientes micrometeorológicos; floresta fechada; clareira natural; biodiversidade.

\section{INTRODUCTION}

Deforestation of Amazonian rainftorests started in the 1960s in line with the national policy of "development of Amazonia", but in response to the expansion of deforested areas, future climatic scenarios of Amazonia have been discussed in combination with general circulation models and field experiments from the end of 1980s (FISCH et al., 1998). Forest biomass and biodiversity have been investigated since the RADAM project in the 1970s. Tree-fall gaps were also investigated along with germination, establishment, and the subsequent growth of pioneer species, mainly Cecropiaceae, in order to explain the plant succession (UHL et al., 1988; MARTÍNEZ-RAMOS et al., 1989). Meteorological measurements have been adapted to gap ecology, but in most cases have only involved preliminary data collection, such as light and temperature

1. Engenheiro Florestal, PhD., Faculty of Integrated Arts and Sciences, Hiroshima University, 1-7-1 Kagamiyama, Higashi-Hiroshima, Hiroshima 739-8521, Japan. tsuchiya@hiroshima-u.ac.jp

2. Engenheiro Florestal, Dr., Centro de Projetos e Estudos Ambientais do Amazonas, Av. Desembargador Anisio Jobim Km 11, Bairro Aleixo No 980, CEP 69083-000, Manaus (AM).piquia@hotmail.com

Recebido para publicação em 17/01/2006 e aceito em 13/10/2008. 
measurements, to compare with seed and seedling responses (THOMPSON and GRIME, 1983; CHAZDON, 1988; ACKERLY and BAZZAZ, 1995). Systematic measurements such as heat balance and evapotranspiration have been conducted mainly in pastures since the 1990s, and researchers' interests have moved to restoration of abandoned pastures and forest utilization with low environmental loads (FEARNSIDE, 1995; VAN LEUWEEN et al., 1997; HIGUCHI et al., 1998; MESQUITA, 2000; LAURANCE and FEARNSIDE, 2002). Among them, there is a movement toward applying the gap-phase succession to afforestation, such as HARTSHORN (1989) and TANAKA (1998). It is thought that the improvement of radiation environments is the largest change at gaps. What is needed is a coupling of the ecological techniques with findings from small-scale meteorological phenomena at gaps. Therefore, the current study aims to measure micrometeorological parameters, which largely differ between a closed forest and a gap, and to compare these results with the species composition and the number of individual trees at each site.

\section{METHODS}

From August to September 2003 and in March 2004, fieldwork was carried out in a closed forest (CF) and at a large-sized tree-fall gap formed in 2001 (20 m width x $40 \mathrm{~m}$ distance: $\mathrm{LG}$ ) in a primary forest. It is called Cascalheira, and is located $40 \mathrm{~km}$ east of Novo Aripuanã $\left(5^{\circ} 18^{\prime} \mathrm{S}, 60^{\circ} 04^{\prime} \mathrm{W}\right)$, about $300 \mathrm{Km}$ south of Manaus, AM (Figure 1). Notable human disturbance has never been occurred at the site either before or after the land was acquired by the Centro de Pesquisas Ecológicas da Amazônia in 1993. Vegetation type is categorized as "canopy-emerged lowland tropical dense forest in the Madeira drainage basin" (TANAKA, 2005). The author explained that not only late successional species are peculiar to primary forests but also numerous tree-fall gaps formed at the end of rainy season, increasing species richness. The yellow latosol (Oxisols) reaches to a depth of 5-6 m of soil (SOUZA, 1991), and a pebble layer called Cascalho is beneath the Oxisols. The thickness of the humus layer is only $5-10 \mathrm{~cm}$. A weak dry season occurs from June to October, with monthly precipitation of about $100 \mathrm{~mm}$. According to the climatic data of National Agency of Water (ANA) from 1991 to 2003, the annual mean temperature is $26.0{ }^{\circ} \mathrm{C}$, humidity is $85 \%$, and precipitation is $3,439 \mathrm{~mm}$.

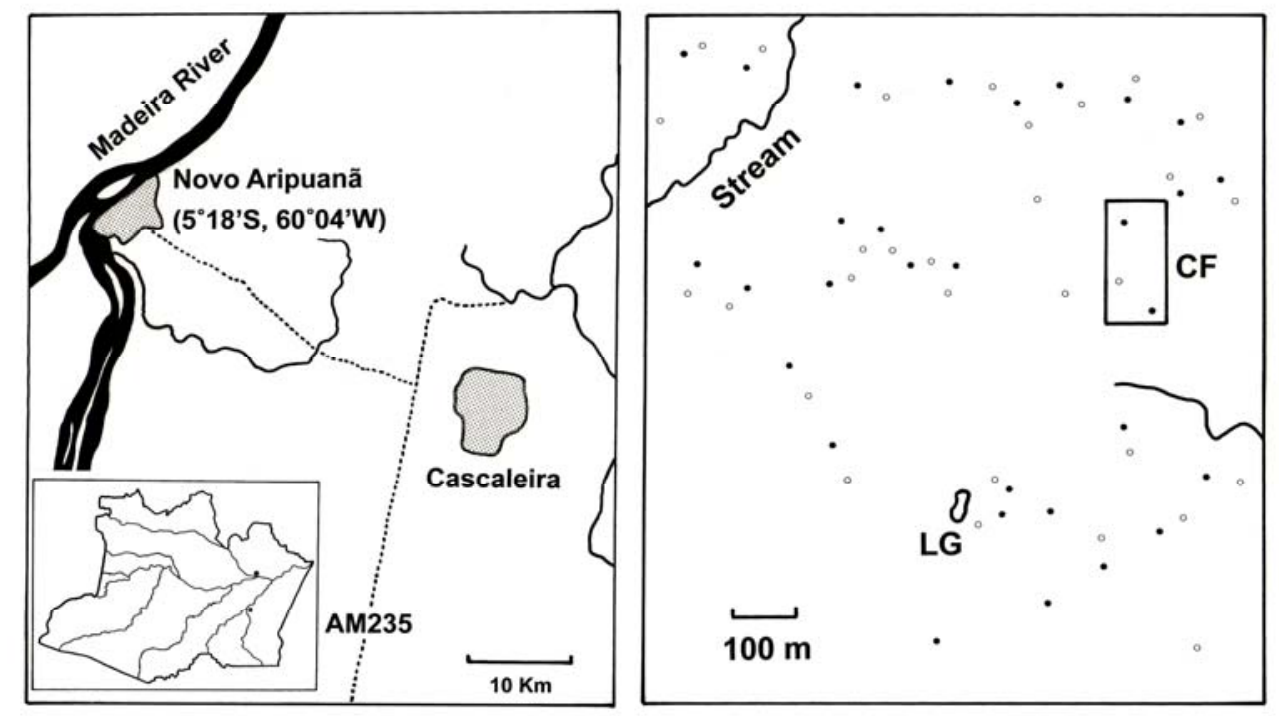

FIGURE 1: Study site (Cascalheira). Location of the micrometeorological measurements (CF: closed forest, LG: large gap), quadrant for forest inventory, and mini-plots $(\bullet: \mathrm{CF}, \circ$ : GAP).

FIGURA 1: Área de estudo (Cascalheira). Localização das observações micrometeorológicas (CF: floresta fechada, LG: capoeira grande), do inventário florestal e das pequenas parcelas ( $\bullet$ : CF, ०: GAP).

A tipping-bucket rain gauge (Ohta, No.34T) was set in CF and LG, and hourly precipitation (P) was stored to a data logger (TandD, RF3) from August $13^{\text {th }}$ to September $12^{\text {th }}$, and March $2^{\text {nd }}$ to $21^{\text {st }}$. A dielectric aquameter sensor (Decagon, ECHO10) for soil moisture (SM) was buried at depths of $0.1,0.3,0.5$, and 1.0 $\mathrm{m}$, and a platinum resistant thermometer for soil temperature (ST) was buried at 0.1 and $0.3 \mathrm{~m}$. Soil samples 
were obtained by core samplers (Daiki, Stainless $100 \mathrm{cc}$ ), and were used to estimate SM from the relationship between the dielectricity and volumetric water content. Four radiation parameters (downward and upward shortwave radiations: $\mathrm{SWd}, \mathrm{SWu}$, longwave radiations: $\mathrm{LWd}, \mathrm{LWu}$ ) were measured using an Eko-MR40 at a height of $1.3 \mathrm{~m}$, and soil heat flux $(\mathrm{G})$ was measured with an Eko-MF81. The data were saved in voltage data loggers (Eko, MP75D). Air temperature $(\mathrm{T})$ and humidity $(\mathrm{H})$ were measured using a thermo-hygrometer (Hioki, No.9680) at 1.5 and $0.1 \mathrm{~m}$ above the ground. Except for the dielectricity, which was recorded every 30 minutes, the parameters were recorded every 10 minutes. Since there was only one set of equipment except for the rain gauge, measurements were shifted; one week for CF (August $21^{\text {st }}-27^{\text {th }}$ ), and one week for LG (September $6^{\text {th }}-12^{\text {th }}$ ) in dry season, six days for CF (March $2^{\text {nd }}-7^{\text {th }}$ ), and six days for LG (March $16^{\text {th }}-21^{\text {st }}$ ) in rainy season. Sky-view photos were taken using a fish-eye lens (Sigma, EX8mmF4) at each site (10 photos each) to estimate the sky-view factor by analyzing the images with software (Mitani, Mac Scope 2.5). A forest inventory was carried out at CF in 2003. Individuals of DBH $\geq 5 \mathrm{~cm}$ were targeted in the area of $1.9 \mathrm{ha}$ (CF: Figure 2). The number of seedlings, whose height was under $50 \mathrm{~cm}$, was counted in 30 mini-plots $\left(4 \mathrm{~m}^{2}\right.$ each) established at the closed forests $(\bullet)$ and gaps $(\circ)$.

\section{RESULTS}

\section{Precipitation and soil moisture}

As shown in Figure 2, there were eight rainfall events from August $13^{\text {th }}$ to September $12^{\text {th }}, 2003$ in dry season. All the cases were squalls and showers brought about by convectional disturbances. The hourly precipitation (P) recorded was $22.0 \mathrm{~mm}$ at $\mathrm{CF}$ and $46.5 \mathrm{~mm}$ at LG at 18:00 on August $15^{\text {th }}$. From March $2^{\text {nd }}$ to $21^{\text {st }}, 2004$ in the rainy season, the number of rainy days amounted to 15 . There was one case in which the $P$ exceeded $20 \mathrm{~mm}$ at $\mathrm{CF}$, and four cases at LG, but they did not reach $30 \mathrm{~mm}$. Instead, the rains lasted longer than those in dry season.
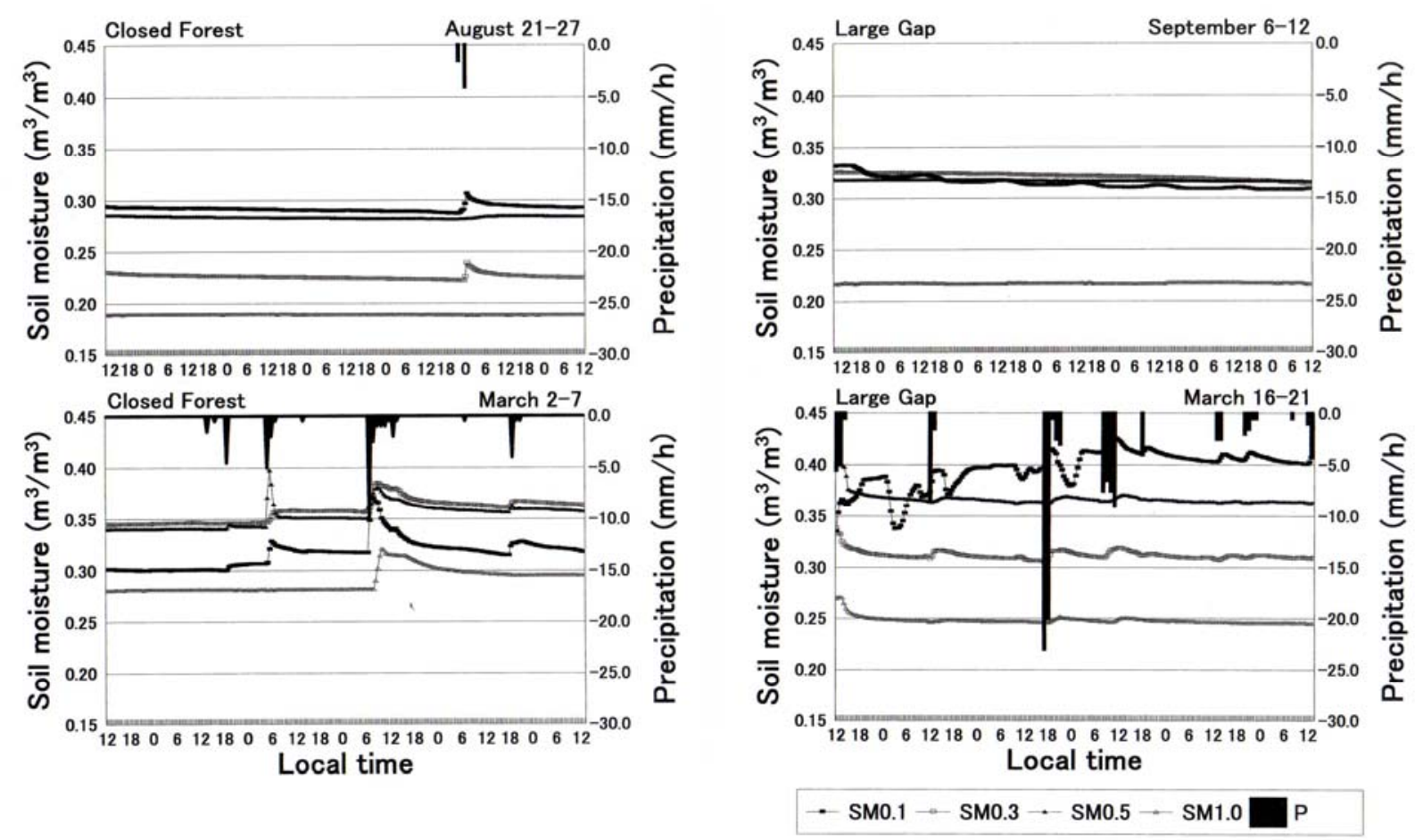

FIGURE 2: Precipitation $(\mathrm{mm} / \mathrm{h})$ and soil moisture $\left(\mathrm{SM}: \mathrm{m}^{3} / \mathrm{m}^{3}\right)$ at four depths of soil in a closed forest and at a large gap in dry season (August to September 2003) and rainy season (March 2004).

FIGURA 2: Precipitação $(\mathrm{mm} / \mathrm{h})$ e água do solo $\left(\mathrm{SM}: \mathrm{m}^{3} / \mathrm{m}^{3}\right)$ em quatro profundidades no solo em floresta fechada e em ambiente de clareira grande, durante a estação seca (agosto a setembro, 2003) e estação chuvosa (março, 2004).

Soil moisture content $\left(\mathrm{SM}: \mathrm{m}^{3} / \mathrm{m}^{3}\right)$ at $\mathrm{CF}$ during August $21^{\mathrm{st}}-27^{\text {th }}$ was the highest at the depth of 0.1 $\mathrm{m}$ (SM0.1: 0.29-0.30), the second highest was SM0.5 (0.28-0.29), next was SM0.3 (0.22-0.23), and the 
lowest one was SM1.0 (0.19) (Figure 2). The SM0.1 responded to the rainfall from August $25^{\text {th }}$ to $26^{\text {th }}$; it increased about $0.02 \mathrm{~m}^{3} / \mathrm{m}^{3}$, and maintained the level later. The response of SM0.3 was similar to that of SM0.1. The SM0.5 slightly increased with a time lag of about six hours, but there was no change in SM1.0. There was no rainfall at LG during September $6^{\text {th }}-12^{\text {th }}$, but SM was higher than that of CF because of the rainfall occurred a week before. The profile was SM0.1 $>$ SM0.3 $>$ SM0.5 $>$ SM1.0. The SM in rainy season greatly changed at both sites. At CF (March $2^{\text {nd }}-7^{\text {th }}$ ), increases and subsequent decreases were observed at all depths on March $5^{\text {th }}$. At LG (March $16^{\text {th }}-21^{\text {st }}$ ), increases and decreases were observed at all depths on the first day when it rained $56.5 \mathrm{~mm}$. The profile was SM0.1 $>\mathrm{SM} 0.5>\mathrm{SM} 0.3>\mathrm{SM} 1.0$. The range of SM was higher in rainy season, and was higher at LG. The SM0.1 responded to a few $\mathrm{mm}$ of rainfall, while SM1.0 seemed to respond when the hourly precipitation reached $10 \mathrm{~mm}$.

\section{Net radiation, soil heat flux, and soil temperature}

In dry season, SWd reached $400 \mathrm{~W} / \mathrm{m}^{2}$ at $\mathrm{CF}$, but it was limited to about two hours each in the morning and afternoon because of the sun-fleck. The SWu was observed at the same time. Both LWd and $|\mathrm{LWu}|$ varied with temperatures from 420 to $500 \mathrm{~W} / \mathrm{m}^{2}$. The $\mathrm{SWd}$ reached $800-1,000 \mathrm{~W} / \mathrm{m}^{2}$, and $\mathrm{SWu}$ rose to $200 \mathrm{~W} / \mathrm{m}^{2}$ at LG. The $\mathrm{LWd}$ was larger than $|\mathrm{LWu}|$ in daytime, and the difference was about $150 \mathrm{~W} / \mathrm{m}^{2}$. The difference was reduced to $20-30 \mathrm{~W} / \mathrm{m}^{2}$ at night. In rainy season, both $\mathrm{SW}$ and $\mathrm{LW}$ were flat at $\mathrm{CF}$. The maximum SWd was about $50 \mathrm{~W} / \mathrm{m}^{2}$. The $\mathrm{SWu}$ was also compressed. The $\mathrm{LWd}$ and $\mathrm{LWu}$ remained at 450 $\mathrm{W} / \mathrm{m}^{2}$ all the day. Radiations at LG were dependent on weather. The SWd and SWu were similar to during dry season, but on rainy days, they were about half that of dry season. The LW also responded to changes in the weather. The relationship of $|\mathrm{LWu}|>\mathrm{LWd}$ was observed both in daytime and nighttime.

Net radiation $(\mathrm{Rn})$ was basically influenced by $\mathrm{SWd}$ because $\mathrm{LWd}=|\mathrm{LWu}|$ and $\mathrm{SWd}>\mathrm{SWu}$. At $\mathrm{CF}$ in dry season, $\mathrm{Rn}$ temporarily reached $100-400 \mathrm{~W} / \mathrm{m}^{2}$ in the morning and afternoon, but it was a little below zero in nighttime (Figure 3). Soil heat flux $(G)$ was positive just before and after noon, but changed to negative at night, keeping $\mathrm{Rn}<\mathrm{G}$. The peak of Rn was $600-700 \mathrm{~W} / \mathrm{m}^{2}$ at $\mathrm{LG}$, and that of $\mathrm{G}$ was $200 \mathrm{~W} / \mathrm{m}^{2}$. Both radiations dropped to $-50 \mathrm{~W} / \mathrm{m}^{2}$ in the evening, and gradually rose up to zero until dawn, keeping the relationship of $\mathrm{Rn}>\mathrm{G}$. In rainy season, they were up to $20-30 \mathrm{~W} / \mathrm{m}^{2}$ at $\mathrm{CF}$. At $\mathrm{LG}$, the maximum $\mathrm{Rn}$ and $\mathrm{G}$ was almost equal to that of dry season. But the changing pattern was serrated because they dropped when it rained.
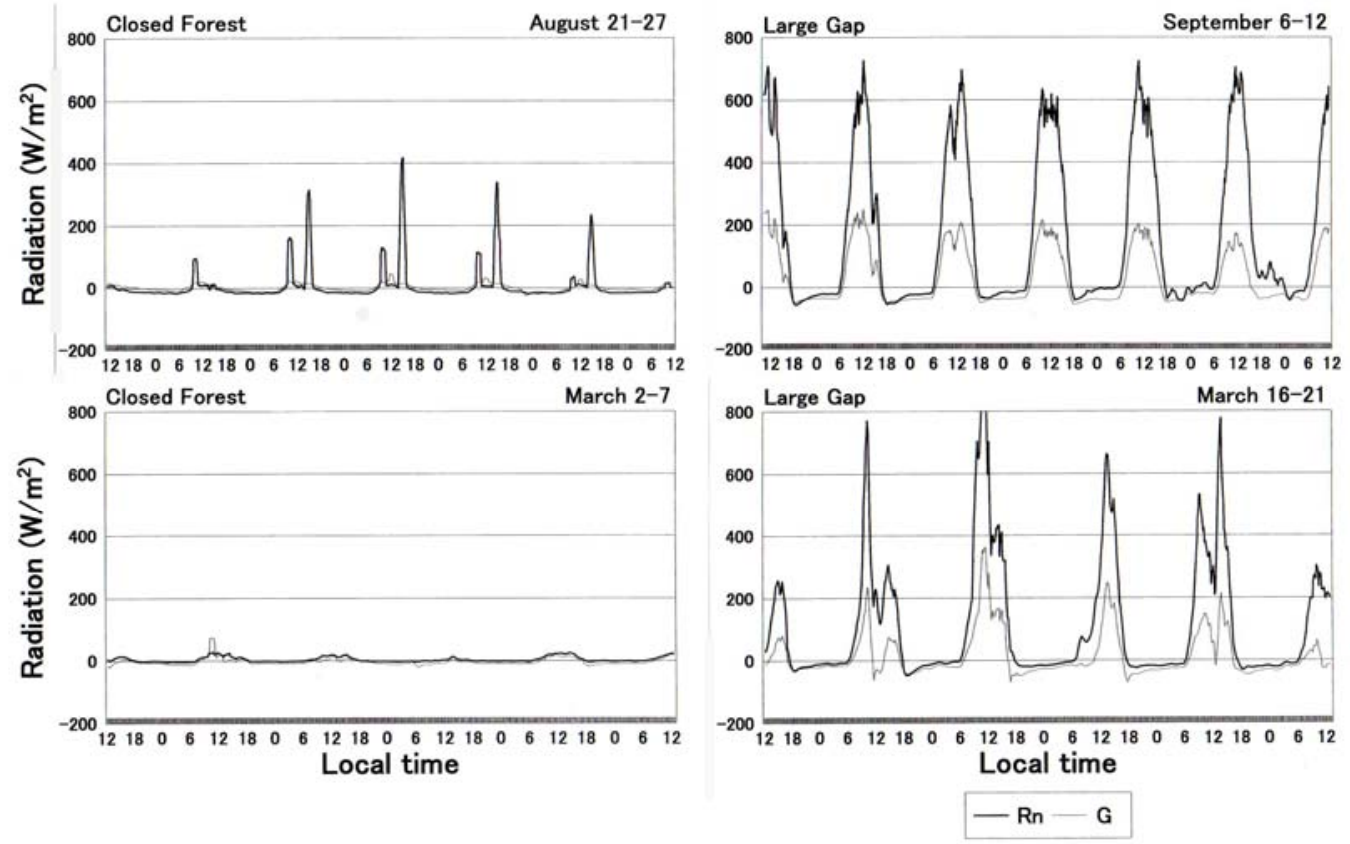

FIGURE 3: Net radiation $\left(\mathrm{Rn}: \mathrm{W} / \mathrm{m}^{2}\right)$ and soil heat flux $\left(\mathrm{G}: \mathrm{W} / \mathrm{m}^{2}\right)$.

FIGURA 3: Radiação líquida $\left(\mathrm{Rn}: \mathrm{W} / \mathrm{m}^{2}\right)$ e fluxo de calor no solo $\left(\mathrm{G}: \mathrm{W} / \mathrm{m}^{2}\right)$.

In dry season, soil temperatures (ST) at two depths changed from $25.0-27 .{ }^{\circ} \mathrm{C}$ at $\mathrm{CF}$. The ST0.1 had 
a diurnal variation $\left(<2.0{ }^{\circ} \mathrm{C}\right)$; it peaked at 18:00-21:00, and bottomed at 9:00-10:00. There was no diurnal variation in ST0.3. At LG, diurnal variation was found in ST0.3 also. There was a time lag between the two depths; ST0.1 peaked at 15:00 and bottomed at 8:00, ST0.3 peaked at 22:00 and bottomed at 12:00. The difference between the depths was ST0.1 $>$ ST0.3 from 9:00 to 0:00, while it was ST0.1<ST0.3 at other times. At CF, the diurnal variation appeared in ST0.1, but was as small as $1.0^{\circ} \mathrm{C}$. No diurnal change was found in ST0.3. A clear change was found at LG, but the fluctuation was smaller than that in dry season (ST0.1: 1.0$3.5^{\circ} \mathrm{C}$, ST0.3: $0.5-2.0^{\circ} \mathrm{C}$ ).

\section{Air temperature and humidity}

Air temperatures $(\mathrm{T})$ at the heights of $1.5 \mathrm{~m}$ and $0.1 \mathrm{~m}$ changed from $22.0-23.0{ }^{\circ} \mathrm{C}$ to $27.0-30.0{ }^{\circ} \mathrm{C}$ at $\mathrm{CF}$ in dry season (Figure 4). The $\mathrm{T}$ fluctuated between $18.0-20.0^{\circ} \mathrm{C}$ and $32.0-34.0^{\circ} \mathrm{C}$ at LG. Dew-point temperature (Tdp) at $\mathrm{CF}$ was lower than $\mathrm{T}$ in daytime, but they were the same from the evening to morning. On the next day of a squall, no difference appeared between Tdp and T. At LG, Tdp increased in the morning and in the evening. In the afternoon, Tdp became lower than $\mathrm{T}$, and the difference expanded to $15{ }^{\circ} \mathrm{C}$ at 1.5 $\mathrm{m}$ and $20{ }^{\circ} \mathrm{C}$ at $0.1 \mathrm{~m}$. At $\mathrm{CF}$ in rainy season, temperatures fluctuated from $23.0^{\circ} \mathrm{C}$ to $28.0{ }^{\circ} \mathrm{C}$. The temperature dropped every time it rained. Because $\mathrm{T}$ was almost equal to Tdp for both heights, the four temperatures seem to overlap into one curve in the figure. At LG, temperatures were influenced by the weather; temperatures as high as in dry season were observed on sunny days, while they did not reach 30.0 ${ }^{\circ} \mathrm{C}$ on rainy days. The daytime Tdp was high due to a large amount of water vapor. There was a case which Tdp0.1 reached $30.0^{\circ} \mathrm{C}$ (March 20).
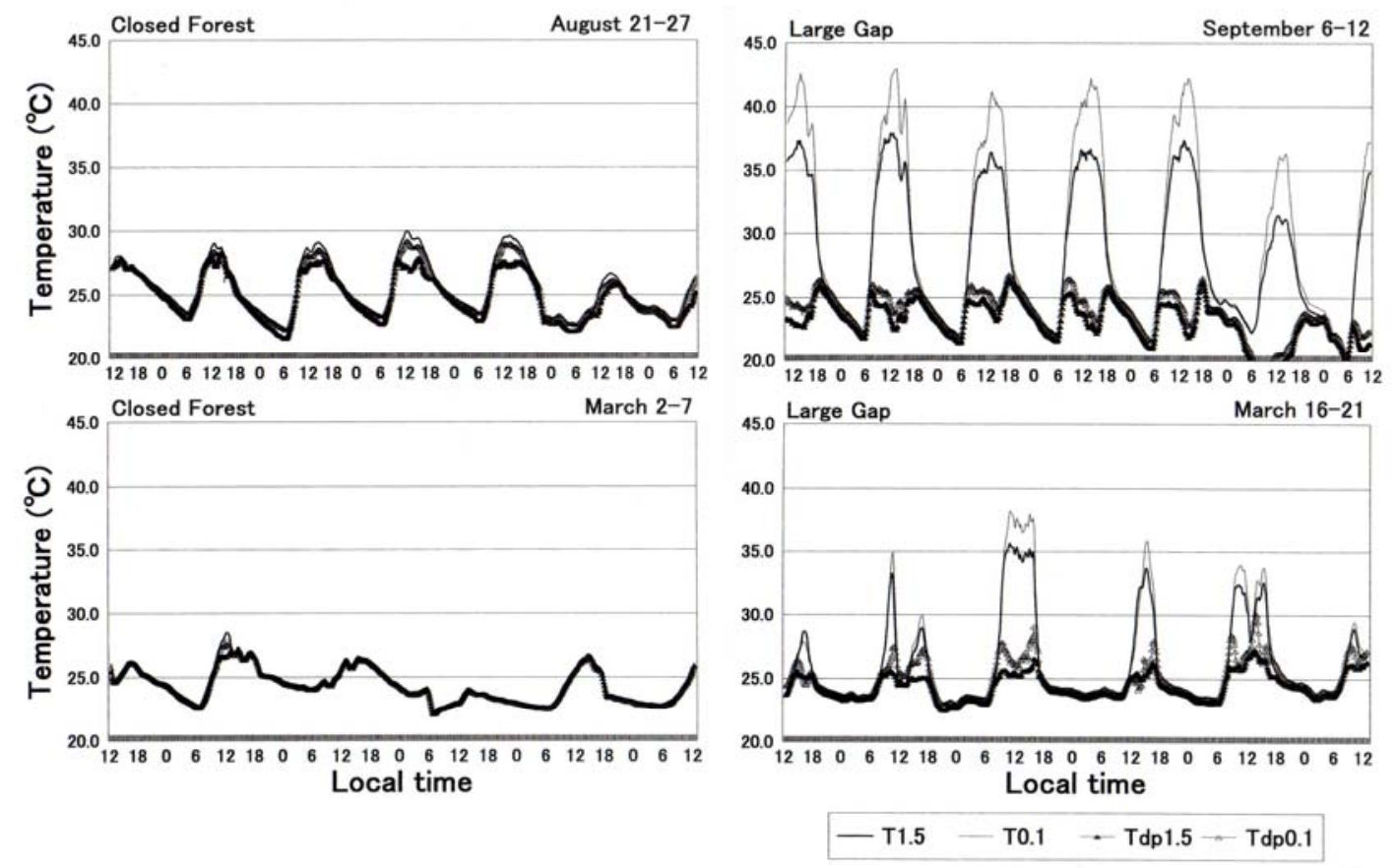

FIGURE 4: Air temperatures $\left(\mathrm{T}:{ }^{\circ} \mathrm{C}\right.$ and dew-point temperatures $\left(\mathrm{Tdp}:{ }^{\circ} \mathrm{C}\right.$ at $1.5 \mathrm{~m}$ and $0.1 \mathrm{~m}$ above the ground.

FIGURA 4: Temperatura do ar $\left(\mathrm{T}:{ }^{\circ} \mathrm{C}\right)$ e temperatura do ponto de condensação do orvalho $\left(\mathrm{Tdp}:{ }^{\circ} \mathrm{C}\right)$ a $1.5 \mathrm{~m}$ e a $0.1 \mathrm{~m}$ à superfície do solo.

Relative humidity at the height of $0.1 \mathrm{~m}$ (H0.1) at CF in dry season was $100 \%$ throughout a week. The H1.5 decreased to $85 \%$ in daytime. At LG, both H0.1 and H1.5 dropped to $40-50 \%$ in daytime, but they reached $100 \%$ at 18:00. The absolute humidity $\left(\mathrm{Y}: \mathrm{g} / \mathrm{m}^{3}\right)$ was similar to Tdp. When Y keeps decreasing even after $\mathrm{T}$ overlapped Tdp, the decrease is regarded as the amount of condensation. On August $24^{\text {th }}$ (a sunny day), the $\mathrm{T}=\mathrm{Tdp}$ occurred at 18:00, and they gradually decreased until the next morning. In the meantime, water vapor $\left(4.0 \mathrm{~g} / \mathrm{m}^{3}\right)$ condensed. The condensation was as small as $1.0 \mathrm{~g} / \mathrm{m}^{3}$ on rainy days. The $\mathrm{Y}$ at $\mathrm{LG}$ was obviously small. In rainy season, H0.1 at CF was $100 \%$ throughout the days, and H1.5 was also $100 \%$ except for on March $3^{\text {rd }}$. At LG, there was a day when $\mathrm{H}$ decreased to the $50 \%$ level, and a day when the 
decrease remained to $80 \%$. The maximum $\mathrm{Y}$ at $\mathrm{CF}$ was about $25.0 \mathrm{~g} / \mathrm{m}^{3}$, but $\mathrm{Y}$ did not fall below $20.0 \mathrm{~g} / \mathrm{m}^{3}$ except for March $5^{\text {th }}$. The amount of condensation was as small as $1.0-2.0 \mathrm{~g} / \mathrm{m}^{3}$. The saturation deficit (Ed: $\mathrm{hPa}$ ) in dry season was $\mathrm{CF}$ (less than $10 \mathrm{hPa})<\mathrm{LG}(20-25 \mathrm{hPa})$. The maximum Ed was about $5 \mathrm{hPa}$ at $\mathrm{CF}$ in rainy season. At LG, it largely changed depending on the weather (6 to $30 \mathrm{hPa}$ and more).

\section{Parameters between the sites and between the seasons}

Table 1 shows the daily averages (Avg.) and the standard deviations (SD) of parameters between CF and LG both in the dry and rainy seasons. The statistics do not include the data of the initial and final days of the measurement periods. The site difference with respect to $\mathrm{SW}$ was $\mathrm{CF}<\mathrm{LG}$ both in dry and rainy seasons, and the value was greater in dry season (D) than in rainy season (R) at both sites. The LW was below zero at both sites and in both seasons, indicating that the energy was emitted from the ground surface to the atmosphere. The $|\mathrm{LW}|$ was greater at LG with no canopy, and the seasonal difference at LG was $\mathrm{D}>\mathrm{R}$. The Rn was $\mathrm{CF}<\mathrm{LG}$ both in dry and rainy seasons. The $\mathrm{Rn}$ at $\mathrm{CF}$ was small in both seasons. The seasonal difference at LG was D $>$ R. The G, ST0.1, and T0.1 were all CF $<$ LG in both seasons, and those in dry season were greater than in rainy season. The H0.1 was $\mathrm{CF}>\mathrm{LG}$ in both seasons. The site difference was larger in dry season $(>20 \%)$, and small in rainy season $(<10 \%)$. The $\mathrm{Y} 0.1$ was $\mathrm{CF}>\mathrm{LG}$ in dry season, and $\mathrm{CF}<\mathrm{LG}$ in rainy season. A large difference was found between the sites $(\mathrm{CF}<\mathrm{LG})$ with respect to Ed in both seasons. The SD of SW, $\mathrm{LW}, \mathrm{Rn}$, and $\mathrm{G}$ were $\mathrm{CF}<\mathrm{LG}$ for both seasons. At $\mathrm{CF}$, the $\mathrm{SD}$ of $\mathrm{SW}$ and Rn were $\mathrm{D}>\mathrm{R}$, but did not exhibit a large difference in the LW and G. At LG, the seasonal difference in SD was small in all the parameters, indicating that they greatly fluctuated in both seasons. The SD of ST0.1, T0.1, and $\mathrm{H}$ were $\mathrm{CF}<\mathrm{LG}$ in both seasons. That of $\mathrm{Y}$ was slightly $\mathrm{CF}>\mathrm{LG}$ in dry season. Although the $\mathrm{SD}$ of $\mathrm{Y}$ was $\mathrm{CF}<\mathrm{LG}$ in rainy season, $\mathrm{SD}$ itself was reduced in comparison to that one in dry season, and the site difference was also as small as 0.2 $\mathrm{g} / \mathrm{m}^{3}$. The sky-view factor was $14.8 \pm 3.9 \%$ at $\mathrm{CF}$, and $43.6 \pm 6.0 \%$ at LG.

TABLE 1: Comparison of meteorological parameters between CF (closed forest) and LG (large gap) in dry and rainy seasons.

TABELA 1: Comparação dos parâmetros micrometeorológicos entre CF (floresta fechada) e LG (capoeira grande) durante as estacões seca e chuvosa.

\begin{tabular}{ccccccccc}
\hline Site & \multicolumn{2}{c}{ CF } & \multicolumn{2}{c}{ LG } & \multicolumn{2}{c}{ CF } & \multicolumn{2}{c}{ LG } \\
\hline Season & \multicolumn{2}{c}{ Dry season } & \multicolumn{2}{c}{ Dry season } & \multicolumn{2}{c}{ Rainy season } & \multicolumn{2}{c}{ Rainy season } \\
Date & \multicolumn{2}{c}{ August 22-26 } & \multicolumn{2}{c}{ September 7-11 } & \multicolumn{2}{c}{ March 3-6 } & \multicolumn{2}{c}{ March 17-20 } \\
\hline Avg. \pm SD & Avg. & SD & Avg. & SD & Avg. & SD & Avg. & SD \\
\hline SW $\left(\mathrm{W} / \mathrm{m}^{2}\right)$ & 20.6 & 58.9 & 218.8 & 272.6 & 5.1 & 7.1 & 147.0 & 226.6 \\
LW $\left(\mathrm{W} / \mathrm{m}^{2}\right)$ & -11.1 & 4.6 & -50.8 & 32.6 & -1.4 & 2.0 & -21.1 & 16.0 \\
Rn $\left(\mathrm{W} / \mathrm{m}^{2}\right)$ & 9.5 & 62.2 & 168.0 & 243.2 & 3.6 & 8.5 & 125.9 & 214.4 \\
G $\left(\mathrm{W} / \mathrm{m}^{2}\right)$ & 0.9 & 11.9 & 28.9 & 87.3 & -3.6 & 11.9 & 19.7 & 81.7 \\
ST0.1 $\left({ }^{\circ} \mathrm{C}\right)$ & 25.9 & 0.4 & 31.1 & 2.0 & 25.1 & 0.5 & 27.6 & 1.0 \\
T0.1 $\left({ }^{\circ} \mathrm{C}\right)$ & 24.8 & 1.9 & 29.5 & 6.8 & 24.5 & 1.3 & 26.8 & 4.1 \\
H0.1 $(\%)$ & 100.0 & 0.0 & 76.8 & 24.3 & 99.8 & 0.2 & 91.6 & 13.7 \\
Y0.1 $\left(\mathrm{g} / \mathrm{m}^{3}\right)$ & 23.7 & 2.6 & 21.3 & 2.0 & 22.3 & 1.7 & 23.0 & 1.9 \\
Ed0.1 $(\mathrm{hPa})$ & 0.0 & 0.0 & 14.5 & 17.8 & 0.3 & 0.1 & 4.4 & 8.1 \\
\hline
\end{tabular}

\section{Species richness}

From forest inventory in the area of 1.9 ha, 1,960 tree individuals $(\mathrm{DBH} \geq 5 \mathrm{~cm}$ ) comprising 49 families and 513 species, and 1,064 palms over 13 species were found. Concerning the species richness, there were 29 species in Burseraceae, 18 in Cecropicaceae, 14 in Meliaceae, 13 in Myristicaceae, 12 in Simaroubaceae, 10 in Violaceae, and 8 in Sterculiaceae, from 52 species in Sapotaceae to 7 species in Melastomataceae (Figure 5). Palm species with more than 100 individuals were Orbignya phalerata (382), Mauritia aculeata (279), Geonoma sp. (164) and Astrocaryum murumuru (130). 


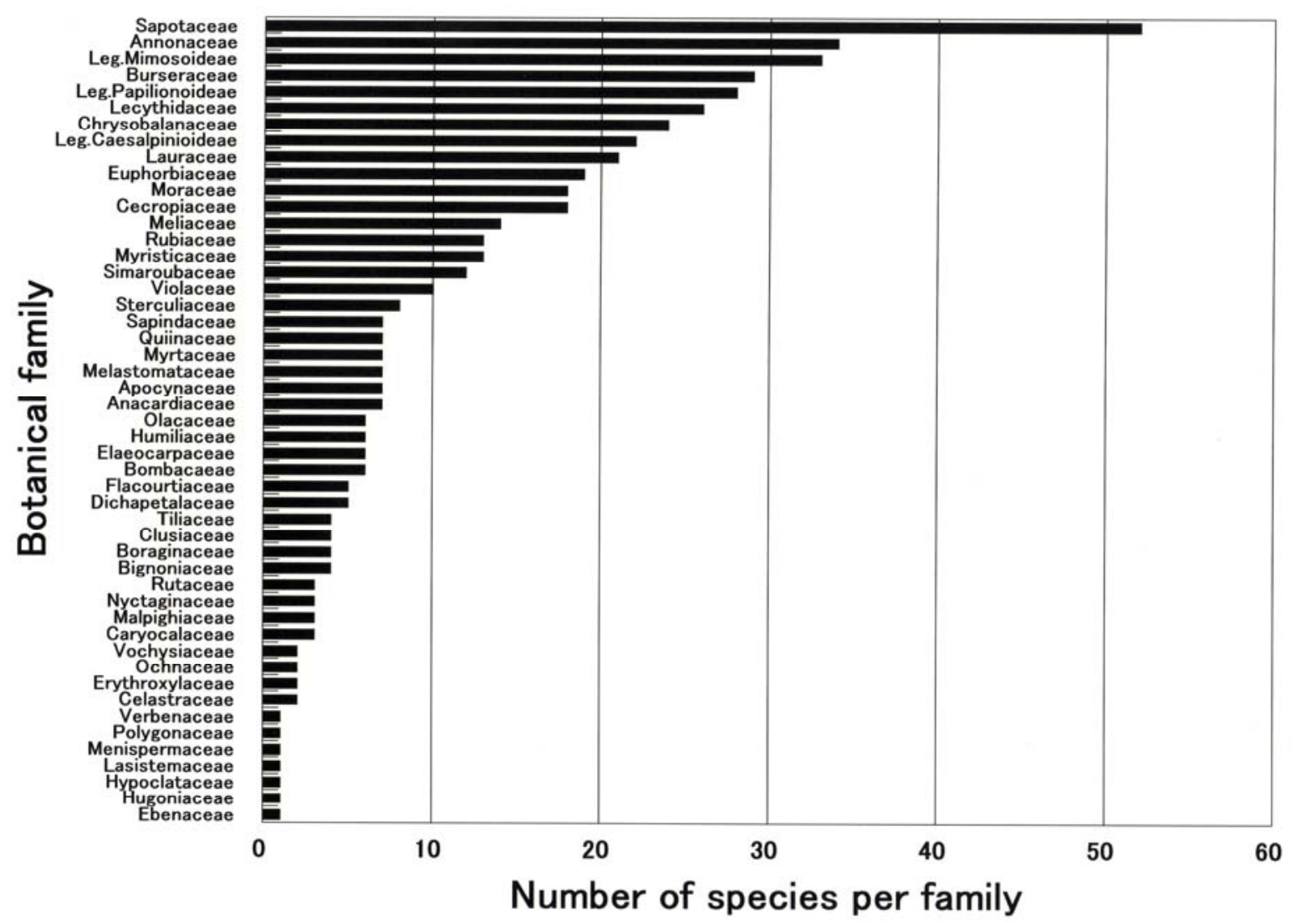

FIGURE 5: Ranking of botanical families sorted by the number of species per family.

FIGURA 5: Classificação das familías de plantas organizadas pelo número de espécies por família.

Seedlings $(<50 \mathrm{~cm})$ at 30 mini-plots did not differ so much in the number of families (CF: 30, GAP: 32 ) and species (77:94), but the number of tree individuals at GAP was about 1.43 times as large as those at CF (CF: 409, GAP: 586) as shown in Table 2. This difference was found in some limited families, such as 11:59 in Cecropiaceae, 1:30 in Leg. Mimosoideae, 40:141 in Leg. Caesalpinioideae, 8:32 in Moraceae, 90:27 in Burseraceae, and 68:30 in Sapotaceae. That of Arecaceae (palm) also exhibited a large difference (CF: 51, GAP: 95).

TABLE 2: Number of seedlings $(<50 \mathrm{~cm})$ per family in 30 mini-plots at CF (closed forest) and at GAP (treefall gap).

TABELA 2: Número de mudas $(<50 \mathrm{~cm})$ por família nos 30 mini-plots em CF (floresta fechada) e em GAP (clareira).

\begin{tabular}{lcc}
\hline \multicolumn{1}{c}{ Botanical family } & CF $\left(/ 120 \mathrm{~m}^{2}\right)$ & GAP $\left(/ 120 \mathrm{~m}^{2}\right)$ \\
\hline Anacardiaceae & 8 & 11 \\
Annonaceae & 17 & 25 \\
Apocynaceae & 0 & 2 \\
Bignoniaceae & 1 & 2 \\
Bombacaceae & 0 & 6 \\
Burseraceae & 90 & 27 \\
Cecropiaceae & 11 & 59 \\
Chrysobalanaceae & 2 & 8 \\
Clusiaceae & 0 & 2 \\
Combretaceae & 1 & 0 \\
Connaraceae & 12 & 11 \\
Elaeocarpaceae & 3 & 0 \\
Euphorbiaceae & 3 & 5 \\
Guttiferae & 5 & 13 \\
Humiliaceae & 6 & 7 \\
Lauraceae & 8 & 10 \\
Lecythidaceae & 18 & 22 \\
Leg.Mimosoideae & 29 & 58 \\
\hline
\end{tabular}

\begin{tabular}{lcc}
\hline \multicolumn{1}{c}{ Botanical family } & CF $\left(/ 120 \mathrm{~m}^{2}\right)$ & GAP $\left(/ 120 \mathrm{~m}^{2}\right)$ \\
\hline Leg. Caesalpinioideae & 40 & 141 \\
Leg.Papilionoideae & 17 & 30 \\
Malpighiaceae & 2 & 2 \\
Melastomataceae & 3 & 4 \\
Meliaceae & 4 & 3 \\
Moniminaceae & 12 & 16 \\
Moraceae & 8 & 32 \\
Myristicaceae & 5 & 9 \\
Myrtaceae & 19 & 28 \\
Nyctaginaceae & 1 & 1 \\
Olacaceae & 0 & 2 \\
Polygonaceae & 0 & 1 \\
Rubiaceae & 9 & 10 \\
Sapotaceae & 68 & 30 \\
Sterculiaceae & 1 & 2 \\
Tiliaceae & 1 & 0 \\
Violaceae & 5 & 7 \\
Arecaceae & 51 & 95 \\
\hline
\end{tabular}




\section{DISCUSSION}

NOBRE et al. (1989) simulated that the albedo would increase from 12.5 to $21.6 \%$, temperature would also increase $\left(1-2{ }^{\circ} \mathrm{C}\right)$, evapotranspiration would decrease from 4.3 to $3.5 \mathrm{~mm} /$ day, sensible heat would increase $(+30 \%)$, and the dry season would be elongated, if the Amazonian rainforests are all changed to pastures. NOBRE et al. pointed out that the bowen ratio in dry season would increase from +1.0 to +3.0 , the minimum temperature at a forest would be $2.5^{\circ} \mathrm{C}$ higher than that at pasture, and the mixing ratio, which is nearly equivalent to the $\mathrm{Y}$, it would be $16 \mathrm{~g} / \mathrm{kg}$ at forest and $10 \mathrm{~g} / \mathrm{kg}$ at pasture. WRIGHT et al. (1992) estimated that the evapotranspiration at pastures would be smaller than at forests. GASH and NOBRE (1997) reported that at pastures Tmax rises, Tmin and $\mathrm{H}$ decrease, and a weakened wind velocity due to small convective energy makes the mixing smaller at night. ALVALÁ et al. (2002) showed that ST and G at a pasture surpassed those at a forest from the measurements in Rondônia. The contrast between forests and pastures-low temperature and high humidity at forests, while high temperature and low humidity at pastures-has been pointed out in these studies. The area of LG targeted in our study is far smaller than that of pastures; however, some results are common with pastures. Namely, parameters related to radiation and temperature at LG are larger than those at CF (Table 1). Fluctuations are also small at CF, meaning that a closed forest mitigates the diurnal and seasonal changes. On the contrary, LG is exposed to environments with a wide range caused by changes in radiation (SWd, Rn) after the elimination of forest canopy. This fact is clear from the sky-view factor at the LG $(43.6 \pm 6.0 \%)$. As for precipitation and soil moisture, the seasonal difference is larger than the difference between the sites, and parameters related to water vapor are also similar to precipitation and soil moisture. From these circumstances, it is concluded that tree-fall gaps, which scatter in primary forests, have fairly different micrometeorological environments from neighboring closed forests.

ALMEIDA et al. (1993) reported that the species richness at Caxiuanã National Park, PA, which had over 50 families and 338 species in an area of 4 ha, was quite high, and that the richness was equivalent to that of primary forests at Camaipi, AP, Breves, PA, and the Xingu River, PA. Although it cannot be directly compared to our results because ALMEIDA et al. measured individuals of $\mathrm{DBH} \geq 10 \mathrm{~cm}$, the number of species at our site exceeds that of the Caxiuanã in spite of its smaller area. Also, through the analysis of the number of species per family between Caxiuanã National Park and Ducke Reserve Forest, AM, LISBOA et al. (1997) described that Sapotaceae, Annonaceae, Leg. Mimosoideae, Leg. Papilionoideae, Lecythidaceae, Chrysobalanaceae, Leg. Caesalpinioideae, Lauraceae, Euphorbiaceae, Moraceae, Rubiaceae, Apocynaceae, and Melastomataceae were the representative families in Amazonia. In our results, botanical families such as Burseraseae, Cecropiaceae, Meliaceae, Myristicaceae, Simaroubaceae, Violaceae, and Sterculiaceae, which have not been described above, are ranked in Figure 5. Frequently-formed tree-fall gaps are thought to be the reason. TANAKA (2005) investigated the history of gaps formed in the past several years in the same area, and estimated the turnover time to be 73 to 119 years. As shown by BROKAW and SCHEINER (1989), there is a possibility that frequently-occurring tree-falls and recoveries mix pioneer species and late successional species, resulting in increases in species richness. Disappearance in forest canopies brings drastic environmental changes. At closed forests, there are shade plants such as Poecilanthe effusa of Leg. Papilionoideae, which remains near the forest floor by sprouting new stems even though the main stem die (TSUCHIYA et al., 2002), but most trees compete toward the forest canopy (CHAMBERS et al., 1998). The solar radiation plays an important role in the extension growth at the forest floor (CHAZDON, 1988), and the neighboring tree individuals also grow due to the edge effect if a gap is formed (CAMARGO and KAPOS, 1995). As stems extend, the percentage of vessel area in stem transection expands to increase the efficiency of absorbing sap (TYREE and EWERS, 1991). TSUCHIYA and HIRAOKA (2001) reported that the percentage of vessel area of an individual with a height of $35 \mathrm{~m}$ is about $30 \%$ in eastern Amazonia. If a tree with such a high percentage of pores is emerged from the canopy layer, the possibility of tree-fall will increase.

Concerning the seedlings in mini-plots shown in Table 2, there were three genera (Cecropia, Coussapoa, Pourouma) in Cecropiaceae at GAP, while there was only Pourouma at CF. The number of Pourouma itself had a large difference (11:37). In Leg. Mimosoideae, the difference in Parkia sp. was outstanding (1:30). This is a fast growing species with light wood density (LOUREIRO et al., 1997). The difference in the number of Leg. Caesalpinioideae was brought about by the genus Tachigalia; 1 at CF and 
84 at GAP. It is known that this species grows fast, and easily falls down. The difference in Moraceae was dependent on the number of Helicostylis sp.; 4 at CF and 25 at GAP. Helicostylis sp. is a medium/understory species, but Moraceae, including this species, is considered to establish fast in the plant succession like Cecropiaceae (FLEMING and WILLIAMS, 1990). A large difference was found in Orbignya phalerata of Arecaceae between CF and LG. This palm is also predominant in gaps. Burseraceae was composed of only Protium sp. It is described that the genus Protium mainly habits in closed forests, but is occasionally found in gaps, too (LOUREIRO et al., 1997). In Sapotaceae, the difference in the number of Chrysophyllum sp. and Micropholis sp. was outstanding (51:12). Both genera are representative canopy emerging species in Amazonia, and the wood density is quite high (SUDAM/DRN, 1981). Just like black pepper, which dislikes strong sunshine and is widely produced in combination with African mahogany in the agro-forestry (TSUCHIYA and LISBOA, 2004), the genera Protium, Chrysophyllum, and Micropholis are also fond of places with small SWd. Buried seeds, seedlings, and juvenile trees sense the development of radiation and temperatures, then germination and stem growth start from species with a fast response such as Cecropia (THOMPSON and GRIME, 1983; ACKERLY and BAZZAZ, 1995).

It has been reported that the surface soil layer at gap has low water contents due to evaporation, while the deep layer with no plant root has high water contents (DENSLOW, 1980). However, in our study, the difference in soil moisture between dry and rainy seasons was about $10 \%$ at the depth of $0.1 \mathrm{~m}$ and a few percent at $1.0 \mathrm{~m}$. Also, the soil moisture was a little higher at LG than at CF in both seasons. It is because the clayish soil has a large water holding capacity and because rainfall directly reaches the soil surface at gaps, while about half of rainfall is trapped by canopies at closed forests (MORAES et al., 1997). FISCH et al. (1998) reported that the soil moisture would have started decreasing at pastures if it were not for precipitation during 10 days in dry season. There are studies stating that grass at pastures with shallow roots wither in dry season, but juvenile trees at pastures survive because the root zone reaches 4-8 $\mathrm{m}$ depth (NEPSTAD et al., 1994; SOMMER et al., 2002; WRIGHT et al., 1992). In Novo Aripuanã area, however, squalls occur. In fact, the monthly mean precipitation from June to September (1991-2000) is $94.1 \mathrm{~mm}$. The water condition recovers with the arrival of a squall even in dry season. Therefore, it is rare for juvenile trees regenerated from tree-fall gaps to decline due to water stress. Rather, changes in radiation conditions are a trigger for plant succession. Even if the pioneer trees disappear, the forest naturally changes into the next succession stage (UHL et al., 1988; MARTÍNEZ-RAMOS et al., 1989).

\section{CONCLUSION}

In this study, micrometeorological environments were measured at a closed forest and tree-fall gap in a canopy-emerged lowland tropical dense forest along the Madeira River, AM. Precipitation and soil moisture were larger in rainy season than dry season at both sites, but the site difference was not clear in either of the seasons. Parameters related to radiation and temperature were greater at a gap than at a closed forest during both seasons, and the diurnal fluctuations were also larger at a gap. It is thought that the disappearance of forest canopy accompanying tree-fall gap has resulted in increases in the number of species per family and the number of seedlings.

\section{ACKNOWLEDGEMENTS}

This study was financially supported by the Nissan Science Foundation and the Japan Society for Promotion of Sciences. We are grateful to Mr. Kiyoshi Nagaoka for assistance in fieldwork.

\section{BIBLIOGRAPHIC REFERENCES}

ACKERLY, D.D.; BAZZAZ, E.A. Seedling crown orientation and interception of diffuse radiation in tropical forest gaps. Ecology, v.76, p.1134-1146, 1995.

ALMEIDA, S.S.; LISBOA, P.B.; SILVA, A.S.L. Diversidade florísticas de uma comunidade arbórea da Estação Científica Ferreira Penna, em Caxiuanã (Pará). Boletim do Museu Paraense Emílio Goeldi, Série Botânica, v.9, p.93-188, 1993.

ALVALÁ, R.C.S.; GIELOWG, R.; ROCHA, H.R. et al. Intradiurnal and seasonal variability of soil temperature, heat flux, soil water content, and thermal properties under forest and pasture in Rondônia. Journal of Geophysical Research-Atmosphere, v.107, 10.1029/2001JD000599, 2002.

BROKAW, N.V.L.; SCHEINER, S.M. Species composition in gaps and structure of a tropical forest. Ecology, v.70, p538-541, 1989. 
CAMARGO, J.L.C.; KAPOS, V. Complex edge effects on soil moisture and microclimate in central Amazonian forest. Journal of Tropical Ecology, v.11, p.205-221, 1985.

CHAMBERS, J.Q. Ancient trees in Amazonia. Nature, v.391, p.135-136, 1998.

CHAZDON, R.L. Sunflecks and their importance to forest understory plants. Advances in Ecological Research, v.18, p.2-54, 1988.

DENSLOW, J.S. Patterns of plant species diversity during succession under different disturbance regimes. Oecologia v.46, p.18-21, 1980.

FEARNSIDE, P.M. Potential impacts of climatic change on natural forests and forestry in Brazilian Amazonia. Forest Ecology and Management, v.78, p.51-70, 1995.

FISCH, G.F.; MARENGO, J.A.; NOBRE, C.A. Uma revisão geral sobre o clima da Amazônia. Acta Amazonica, v.28, p.101-126, 1998.

GASH, J.H.C.; NOBRE, C.A. Climatic effects of Amazonian deforestation: some results from ABRACOS. Bulletin of American Meteorological Society, v. 71, p.19-32, 1997.

HARTSHORN, G.S. Application of gap theory to tropical forest management: natural regeneration on strip clear-cuts in the Peruvian Amazon. Ecology, v.70, p.567-569, 1989.

HIGUCHI, N.; CAMPOS, M.A.A.; SAMPAIO, P.T.B. et al. Pesquisas florestais para a conservação da floresta e reabilitação de áreas degradadas da Amazônia, Manaus, INPA, 1998, 264p.

LAURANCE, W.F.; FEARNSIDE, P.M. Issues in Amazonian development. Science, v.295, p.1643, 2002.

LISBOA, P.B.; SILVA, A.S.L.; ALMEIDA, S.S. Florística e estrutura dos ambientes. In: CAXIUANÃ (LISBOA, P.B., ed.), Belém, Museu Paraense Emílio Goeldi, 1997, p163-193.

LOUREIRO, A.A.; FREITAS, J.A.; FREITAS, C.A.A. Essências madeireiras da Amazônia, Vol.3, Manaus, INPA, 1997, 103p.

MARTÍNEZ-RAMOS, M.; ALVAREZ-BUYLLA, E.; SARUKHÁN, J. Tree demography and gap dynamics in a tropical rain forest. Ecology, v.70, p.555-558, 1989.

MESQUITA, R.D.G. Management of advanced regeneration in secondary forests of Brazilian Amazon. Forest Ecology and Management, v.130, p.131-140, 2000.

MORAES, J.C.; COSTA, J.P.R.; ROCHA, E.J.P. et al. Estudos hidrometeorológicos na bacia do Rio Caxiuanã. In: CAXIUANÃ (LISBOA, P.B., ed.), Belém, Museu Paraense Emílio Goeldi, 1997, p.85-95.

NEPSTAD, D.C.; CARVALHO, C.R.; DAVIDSON, E.A. et al. The role of deep roots in the hydrological and carbon cycles of Amazonian forests and pastures. Nature, v.372, p.666-669, 1994.

NOBRE, C.A.; SHUKLA, J.; SELLERS, P.J. Impactos climáticos do desmatamento da Amazônia. Climanálise, v.4, p.44-55, 1989.

NOBRE, C.A.; SELLERS, P.J.; SHUKLA, J. Amazonian deforestation and regional climate change. Journal of Climatology, v.4, p.957-988, 1991.

SOMMER, R.; SÁ, T.D.A.; VIELHAUER, K. et al. Transpiration and canopy conductance of secondary vegetation in the Eastern Amazon. Agricultural and Forest Meteorology, v.112, p.103-121, 2002.

SOUZA, C.G. Solos. In: GEOGRAFÍA DO BRASIL, Vol.3, REGIÃO NORTE, Rio de Janeiro, IBGE, 1991, p.123136.

SUDAM/DRN. Madeiras da reserva florestal de Curuá-Una estado do Pará, caracterização anatômica, propriedades gerais e aplicações, Belém, SUDAM, 1981, 117p.

TANAKA, A. Ecofisiologia do estabelecimento de plântulas em plantios de enriquecimento em Novo Aripuanã. Dissertação apresentada ao programa de pós-graduação em biologia tropical e recursos naturais do convénio. UFAM-INPA, 1998. 113p. Dissertação (Mestrado em Ciência de Florestas Tropicais)-Universidade Federal do Amazonas-Instituto Nacional de Pesquisas da Amazônia, 1998.

TANAKA, A. Avaliação de anéis de crescimento de espécies florestais de terra-firme no Município de Novo Aripuanã-AM. UFAM-INPA, 2005. 178p. Dissertação (Doutorado em Ecologia)-Universidade Federal do AmazonasInstituto Nacional de Pesquisas da Amazônia, 2005.

THOMPSON, K.; GRIME, J.P. A comparative study of germination responses to diurnally-fluctuating temperatures. Journal of Applied Ecology, v.20, p.141-156, 1983.

TSUCHIYA, A.; HIRAOKA, M. Differences of primary and secondary terra firme forests along the Uaicurapa River near Parintins, AM according to the relationship between individual tree size and vessel area in stem cross sections. Boletim do Museu Paraense Emílio Goeldi, Série Botânica, v.17, p.367-387, 2001. 
TSUCHIYA, A.; HIRABUKI, Y.; NISHIZAWA, T. et al. The relationship between vessel parameters and the development of strata in the early stages of secondary forest succession in Amazonia. Acta Amazonica, v.32, p.241256, 2002.

TSUCHIYA, A.; LISBOA, P.B. Tree growth and microclimatic mitigation in mahogany- black pepper agro-forestry at Parque Ecológico de Gunma, PA, Brazil. Geographical Review of Japan, v.77, p.321-335, 2004.

TYREE, M.T.; EWERS, F.W. The hydraulic architecture of trees and other woody plants. New Phytologist, v.119, p.345-360, 1991.

UHL, C.P.; CLARK, K.; DEZZEO, N. et al. Vegetation dynamics in Amazonian treefall gaps. Ecology, v.69, p.751$763,1988$.

VAN LEUWEEN, J.; MENEZES, J.M.T.; MOREIRA GOMES, J.B. et al. Sistemas agroflorestais para a Amazônia: importância e pesquisas realizadas. In: DUAS DÉCADAS DE CONTRIBUIÇÃO DO INPA A PESQUISA AGRONÔMICA NO TRÓPICO ÚMIDO (NODA, H.; SOUZA, L.A.G.; MENEZES-FONESCA, O.J., eds.), Manaus, INPA, 1997, p.131-146.

WRIGHT, I.R.; GASH, J.H.C.; ROCHA, H.R. et al. Dry season micrometeorology of central Amazonian ranchland. Quarterly Journal of Royal Meteorological Society, v.118, p.1083-1089, 1992. 